\title{
Biofortification: Zinc Enrichment Strategies in Crops
}

ISSN: 2637-7659

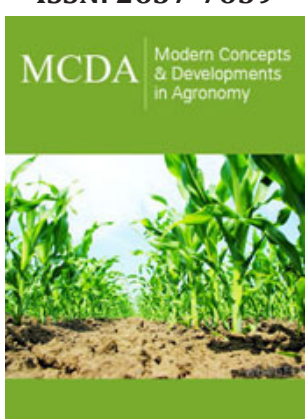

*Corresponding author: Süleyman TABAN, Department of Soil Science and Plant Nutrition, Faculty of Agriculture, Ankara University, 06110 Ankara, Turkey

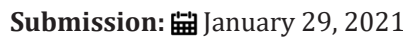

Published: 眥 February 24, 2021

Volume 8 - Issue 1

How to cite this article: Hanife AKÇA, Süleyman TABAN. Biofortification: Zinc Enrichment Strategies in Crops. Mod Concep Dev Agrono. 8(1). MCDA. 000679. 2021. DOI: 10.31031/MCDA.2021.08.000679

Copyright@ Süleyman TABAN. This article is distributed under the terms of the Creative Commons Attribution 4.0 International License, which permits unrestricted use and redistribution provided that the original author and source are credited.

\section{Hanife AKÇA and Süleyman TABAN*}

${ }^{1}$ Department of Soil Science and Plant Nutrition, Faculty of Agriculture, Ankara University, 06110 Ankara, Turkey

\section{Abstract}

Zinc deficiency causes the major health problems in human. Deficiencies of zinc affect over one-half of the world's population. Food fortification provides especially the improvement of the microelement content of the nutrients and thus the healthy nutrition and the increase of the microelement bioavailability. Progress has been made to control micronutrient deficiencies through food fortification, but new approaches are needed, especially in developing countries. Biofortification is the process of increasing the natural content of bioavailable nutrients in plants. Biofortified crops can reduce the problem of micronutrient malnutrition in a cost-effective way. Different and effective fertilization strategies could be a rapid solution to the zinc deficiency in crops.

Keywords: Biofortification; Zinc; Crops

\section{Introduction}

The balanced and healthy nutrition of our population will be one of the priority issues in the future, as it is today. All living organisms need microelements such as: $\mathrm{Zn}, \mathrm{Fe}, \mathrm{Mn}, \mathrm{Cu}$, Mo as well as macro elements to maintain their metabolic activities, and they meet this need with nutrition [1]. Malnutrition is seen by WHO as a worldwide health risk factor as well as infectious diseases and obesity [2]. The malnutrition problem is common in low and middleincome countries. Micronutrient deficiencies such as iron, zinc, and vitamin A are a global health risk in worldwide. Micronutrients play key roles in the normal functioning of the human body system [3].

It has been determined that two thirds of the world population face serious health problems due to not getting one or more of the mineral elements at a sufficient level. Today, it has been determined that people are most commonly affected by zinc $[1,4]$ and iron $[1,4-$ 6] deficiency. Zinc deficiency is an important problem especially in cereal-based diets. The mortality rate in children under the age of 5 who cannot get enough zinc from the food they eat has been determined as $4.4 \%$ worldwide [7]. Zinc deficiency causes infertility in humans, delayed healing of wounds, mental retardation, etc. it has many negative effects. Besides, zinc is an element that has very important functions in the human body and is necessary for the growth and reproduction of all cells. It is also involved in the structure of enzymes and proteins that play a role in removing free radicals from to cell or cell wall, which are the cause of tissue damage and cell death.

The main reason for $\mathrm{Zn}$ and Fe deficiency in humans is due to the widespread nutrition of grains and legumes and the low bioavailability of these elements in cereal and legume groups [8]. The high content of phytic acid, fiber, and tannins in this group of plants significantly reduces the bioavailability of $\mathrm{Zn}$ and Fe elements [9]. Therefore, increasing the $\mathrm{Zn}$ and $\mathrm{Fe}$ contents and/or phytic acid, etc. It is of great importance to increase the microelement content of basic foods in human nutrition by reducing the factors that negatively affect microelement usefulness.

\section{Zinc Enrichment Strategies}

The amount of zinc in the soil varies depending on the properties of the main material of the soils. For example, although the zinc concentration is high in soils composed of basic volcanic rocks, the zinc concentration is low in soils composed of the parent material with high silicon content. Similarly, sandy soils contain less zinc than soils with high clay content. 
Soil $\mathrm{pH}$ is quite effective parameter on the solubility of zinc in soils. Under conditions with soil $\mathrm{pH}<7, \mathrm{Zn}^{+2}$ form of $\mathrm{Zn}$ is dominant, whereas under $\mathrm{pH}>7 \mathrm{ZnOH}^{+}$is dominant. Under conditions where soil pH is 5 , the amount of $\mathrm{Zn}^{+2}$ is $6.5 \mathrm{mg} \mathrm{kg}^{-1}$, while it decreases to $0.007 \mu \mathrm{g} \mathrm{kg}^{-1}$ when the $\mathrm{pH}$ is 8 [10]. Zinc: forms soluble complexes in the soil with chlorine, phosphate, nitrate and sulphate ions, and the solubility of the compounds formed with neutral sulphate and phosphate ions is higher. The $\mathrm{ZnSO}_{4}$ compound increases the solubility of $\mathrm{Zn}^{+2}$ cations in the soil and the $\mathrm{Zn}$ availability increases with the application of fertilizers with a physiological acid character for instance, ammonium sulphate $\left[\left(\mathrm{NH}_{4}\right)_{2} \mathrm{SO}_{4}\right.$. Zinc forms both soluble and insoluble organic complexes with organic matter in the soil, and soluble complexes with organic acids with low molecular weight, and consequently the amount of soluble $\mathrm{Zn}$ in the soil increases. The increase in the amount of soluble $\mathrm{Zn}$ in the soil with the application of organic fertilizers and it can be explained by the formation of solubility.

Zinc is one of the essential microelements for the normal and healthy growth and reproduction of plants. Zinc is included in the group of essential trace elements and also defined as a micronutrient element due to its low concentrations of 5-100mg $\mathrm{kg}^{-1}$ in plant tissues. Among these elements, iron, copper, zinc, manganese as well as cobalt, chromium, iodine and selenium are important microelements in the food chain [11]. Zn plays a role in the activity of many enzymes such as functional, structural and regulatory in plants [12]. Moreover, zinc is effective on carbohydrate metabolism, sucrose and starch formation, protein metabolism, membrane integrity and auxin metabolism in the plant.

Zinc plays important role in the cellular functions of all living organisms and also plays a role in the development of the human immune system. The optimum daily intake of $\mathrm{Zn}$ in adults should be $15 \mathrm{mg}$. Zinc acts as a catalytic or structural component in various body enzymes in humans as well as in plants $[13,14]$. Zinc is a key component of many important enzymes such as RNA polymerase, superoxide dismutase, lactate dehydrogenase, alkaline phosphatase, aldolase, phospholipase (Srivastra and Gupta 1996). Zinc deficiency may cause several serious disorders such as the development of embryos, fetuses, babies, and young children also disrupts the immune system, and causes late recovery of cells [15]. It is stated that $4 \%$ of the sickness and disability of children under the age of 5 in low-income countries is due to the lack of $\mathrm{Zn} \mathrm{[7].}$ It has been shown that diarrhea and respiratory diseases seen in humans are reduced with zinc supplementation [16]. Insufficient intake of Zn in human dietary cause Zn deficiency. Zn deficiency results negative situations such as hair loss, memory loss and weakening of body muscles occur in human [17]. According to studies, while an adult man needs $11 \mathrm{mg}$ of $\mathrm{Zn}$ a day, women should consume $9 \mathrm{mg}$ of $\mathrm{Zn}$ per day. In women, this amount should be 13$15 \mathrm{mg} \mathrm{Zn}$ day $^{-1}$ during pregnancy. $3 \mathrm{mg} \mathrm{Zn}$ day $^{-1}$ for babies aged 7

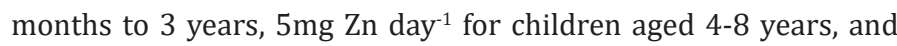
$8 \mathrm{mg} \mathrm{Zn}$ day $^{-1}$ for children aged 9-13 years $[4,18]$. Zinc is usually stored in the husks of grains and the grains are transformed into flour, and it causes Zn deficiency in grain-fed societies. Beef, chicken meat, peanuts, almonds, walnuts, oats, yoghurt, cheese and milk are known as zinc-rich foods [19]. The high content of phytic acid, fiber and tannin, especially in cereal group plants, significantly reduces the bioavailability of $\mathrm{Zn}$ and Fe elements [9,20].

The bioavailability of zinc is very low in foods containing high amounts of phytic acid (FA) or phytate [21]. Phytic acid is the main storage form of phosphorus in grains, legumes and oilseeds. Phytic acid forms insoluble complexes, especially $\mathrm{Zn}, \mathrm{Fe}$ and $\mathrm{Ca}$, which cannot be digested or absorbed in the human body due to the absence of phytase enzymes in the human intestine [22]. Many studies indicated that choosing food with low phytate content increases the absorption of $\mathrm{Zn}, \mathrm{Fe}$ and, Ca compared to the consumption of food products with high phytate content [23-27]. Weaver [28] and Hussain et al. [29] reported that the FA/Zn molar ratio can be used as an index to determine the unavailable of $\mathrm{Zn}$, moreover, the International Zinc Nutrition Advisory Group (IZiNGC) reported that only the FA/Zn molar ratio can be used to determine the negative effect of FA on Zn bioavailability [30]. If diets with high phytate content (unrefined grain-based diets) have a FA/Zn molar ratio greater than $18, \mathrm{Zn}$ absorption is $18 \%$ and $25 \%$ for men and women, respectively, and if the FA/Zn molar ratio is $4-8, \mathrm{Zn}$ It is estimated to be $26 \%$ and $34 \%$ in men and women, respectively [31]. According to the World Health Organization, the FA/Zn molar ratio should be $\leq 15$ for $\mathrm{Zn}$ while this ratio should be $<1$ for Fe [18].

It is a term that encompasses food fortification, the improvement of especially the microelement content of the foods, and consequently, the increase of healthy nutrition and microelement bioavailability [32]. Fortification involves adding nutrients to food products such as adding iodine to table salt or adding $\mathrm{Fe}, \mathrm{Zn}$, and folate to flour used in bread making. A disadvantage of these applications is that the additives have limited stability. For instance, folate added to rice becomes more soluble at high temperatures, and when the rice is boiled, it completely dissolves [33]. A second disadvantage is that additives negatively affect the quality of the foods they are added to in the long term. An example of this situation is that ferrous additives oxidize over time and spoil deteriorate the taste of the foods [34]. The third and most limiting disadvantage is that these applications/approaches are suitable for developed countries with technical infrastructure and distribution networks, and this is not suitable for developing countries that earn their living from agriculture [33].

Biofortification, on the other hand, avoids the other three applications/approaches by covering the development of nutrientintensive plants that can be grown and distributed using existing agricultural practices. While unnatural additives are required with fortification, nutrients are naturally synthesized and accumulated by plants in biofortification [35]. Agricultural biofortification, or biological enrichment, is based on the application of inorganic fertilizers to increase the mineral element concentration in the edible parts of plants and/or the movement and solubility of mineral elements in the soil [36]. Agronomic biofortification is 
simple and inexpensive but needs special attention in terms of the source of nutrients, application method, and effects on the environment. Biofortification is an effective and inexpensive method of increasing and improving the microelement content of foods, which are of great importance for the health of the human population especially in developing countries but needs special attention in the way of source of nutrients and effects on the environment [37]. Application of zinc in soil and/or foliar offers a quick solution to increase $\mathrm{Zn}$ concentration in cultivated plants [20,38-54] (Table 1). Although zinc application is an effective way to increase the yield and microelement concentration of crops, many producers in the world (especially in developing countries) [55]. Zn absorption in humans can be increased by decreasing the phytic acid/zinc molar ratio by reducing the phytic acid content of the grain, especially with agricultural biofortification (soil/foliar fertilization, etc.) $[56,57]$.

Table 1: Different methods used for zinc biofortification in some crops.

\begin{tabular}{|c|c|c|}
\hline Crops & Methods & References \\
\hline Wheat (Triticum aestivum) & Soil, Foilar, Priming, Soil+Foliar & $\begin{array}{c}\text { Taban et al. [38], Dhawial et al. [39], Pavia et al. [40], Liu et al. [41], Akça } \\
\text { [20] }\end{array}$ \\
\hline Maize (Zea Mays) & Soil, Foliar, Priming & Liu et al. [42], Zhang et al. [43], Martínez-Cuesta et al. [44] \\
\hline Rice (Oryza Sativa) & Soil, Soil+Foliar & $\begin{array}{c}\text { Özcan [45], Özcan et al. [46], Özcan [47], Phuphong et al. [48], Grija Veni et } \\
\text { al. [49] }\end{array}$ \\
\hline Lettuce (Lactuca sativa) & Foliar & Tang et al. [50], Gao et al. [51], Adrees et al. [52] \\
\hline Onion (Allium cepa) & Foliar & Rafie et al. [53] \\
\hline $\begin{array}{l}\text { Common bean (Phaseolus } \\
\text { vulgari) }\end{array}$ & Foliar+Priming & Tabesh et al. [54] \\
\hline
\end{tabular}

The source, method, time, and rates of $\mathrm{Zn}$ applications in agricultural biofortification should be well known and developed [5]. Zinc is usually applied to plants in the form of $\mathrm{ZnSO}_{4}$ or synthetic chelates [20,37,38,57] (Shuman 1998, Broadley et al. 2007). The enrichment process with zinc can be exemplified as soil applications, root dipping, seed coating (priming) and leaf application [58]. Soil applications give more results in applying macronutrients to the plant. For micronutrients, it is more effective to apply mostly by spraying from the leaves (Harris et al. 2008). Examples of inorganic zinc sources are zinc oxide $(\mathrm{ZnO})$, zinc carbonate $\left(\mathrm{ZnCO}_{3}\right)$, zinc sulphate $\left(\mathrm{ZnSO}_{4} \cdot 7 \mathrm{H}_{2} \mathrm{O}\right)$, zinc nitrate $\left[\mathrm{Zn}\left(\mathrm{NO}_{3}\right)_{2}\right]$ and zinc chloride $\left(\mathrm{ZnCl}_{2}\right)$. Among the inorganic zinc sources, zinc sulphate $\left(\mathrm{ZnSO}_{4} \cdot 7 \mathrm{H}_{2} \mathrm{O}\right)$ is one of the most widely used $\mathrm{Zn}$ fertilizers in the world. Foliar concentrated zinc oxide $(\mathrm{ZnO})$ solutions can be used in zinc fertilization, but its use is restricted due to particle size [59]. Synthetic chelates are usually a special complex formed by having chelating properties like Ethylene Diamine Tetra-Acetic Acid (EDTA) and combined with a metal ion [60]. Other synthetic chelates are ligands such as Diethylene Triamine Penta-Acetic Acid (DTPA) and Hydroxy-EDTA (HEDTA), but EDTA is by far the most widely used chelating form. In recent years, Zn-amino acid complexes (histidine, lysine, glysine, methionine, etc.) have been synthesized and applied as a natural and effective $\mathrm{Zn}$ source in foliar fertilization $[20,61]$. The transport of amino acids in plants is of great importance for plants. Translocation of amino acids occurs in both phloem and xylem. Therefore, the translocation of amino acids helps the recycling of nitrogen between roots and shoots and accelerates the translocation of immobile nutrients, namely $\mathrm{Zn}$, in the plant [62]. Besides, the addition of urea to zinc fertilizer in the foliar application is an effective strategy for increasing the transport of zinc within the plants $[20,63]$. In the application of zinc from the soil, zinc applications will be a separate strategy, taking into account the plants growth periods.

\section{Conclusion}

Plants are at the beginning of the food chain and make loads of nutrients for other organisms to eat. Therefore, improving the uptake of minerals from the soil and increasing their movement and bioavailability in the edible parts of the plant will benefit human and animal nutrition. Besides, biofortification will be necessary in the future to fully understand the number of nutrients in the soilplant ecosystem and holds great effect for malnutrition problems in human health and it will be the potential way to provide more nutrients for the world population. 


\section{References}

1. Welch RM, Graham RD (2004) Breeding for micronutrients in staple food crops from a human nutrition perspective. J Exp Bot 55(396): 353-364.

2. World Health Organization (WHO) (2017) Double burden of malnutrition. Geneva, Switzerland.

3. Ohanenye IC, Emenike CU, Mensi A, Medina Godoy S, Jin J, et al. (2020) Food fortification technologies: Influence on iron, zinc and vitamin A bioavailability and potential implications on micronutrient deficiency in sub-Saharan Africa. Scientific African 11: e00667.

4. Hotz C, Brown KH, Rivera JA, Bhutta Z, Gibson RS, et al. (2004a) Assessment of the risk of zinc deficiency in populations and options for its control. Food Nutr Bull 25(Supplement 2): 91-204.

5. Graham RD (2008) Micronutrient deficiencies in crops and their global significance, In: Micronutrient deficiencies in global crop production Alloway BJ (Ed.), Springer, Dordrecht, Netherlands, pp. 41-61.

6. White PJ, Broadley MR (2009) Biofortification of crops with seven mineral elements often lacking in human diets-iron, zinc, copper calcium, magnesium, selenium, and iodine. New Phytol 182(1): 49-84.

7. Black RE, Allen LH, Bhutta ZA, Caulfield LE, de Onis M, et al. (2008) Maternal and child undernutrition: global and regional exposures and health consequences. Lancet 371(9608): 243-260.

8. Hurrell RF (2001) Modifying the composition of plant foods for better human health. In: Crop Science: Progress and Prospects. Nösberger J, Geiger HH, Struik PC (Eds.), CABI Publishing, Bristol, England, pp. 53-64.

9. Raboy V (2001) Seeds for a better future: 'Low phytate' grains help to overcome malnutrition and reduce pollution. Trends Plant Sci 6(10): 458-462.

10. Kiekens L (1995) Zinc. In: Heavy Metals in Soils ( $2^{\text {nd }}$ edn), Alloway B] (Ed.), Blackie Academic and Professional, London, pp. 284-305.

11. Alloway BJ (2008) Zinc in soils and crop nutrition. ( $2^{\text {nd }}$ edn), published by IZA and IFA, Brussels, Belgium.

12. Brown PH, Cakmak I, Zhang Q (1993) Form and function of zinc in plants. Chap 7, In: Zinc in Soils and Plants. Robson AD (Ed.), Kluwer Academic Publishers, Dordrecht, Netherlands, pp. 90-106.

13. Zimmermann M (2001) Micronutrients in health and disease. Georg Thieme Verlag, Stuttgart, Germany.

14. Lukaski HC (2004) Vitamin and mineral status: effects on physical performance. Nutrition 20(7-8): 632-644.

15. Hambidge M, Cousins R, Costello R (2000) Zinc and health: current status and future directions: introduction. J Nutr 130(5S Suppl): 1341S-1519S

16. Aggarwal R, Sentz J, Miller MA (2007) Role of zinc administration in prevention of childhood diarrhea and respiratory illnesses: a metaanalysis. Pediatrics 119(6): 1120-1130.

17. Morley JE (2004) The top 10 hot topics in aging. J Gerontol a Biol Sci Med Sci 59(1): 24-33.

18. FAO (2005) Vitamin and Mineral Requirements in Human Nutrition, $\left(2^{\text {nd }}\right.$ edn), World Health Organization, Geneva, Switzerland.

19. Cakmak I (2002) Plant nutrition research priorities to meet human needs for food in sustainable ways. Plant and Soil 247: 3-24.

20. Akça H (2020) Development of zinc-enrichment strategies in bread wheat. Ankara University, Graduate School of Natural and Applied Sciences, Department of Soil Science and Plant Nutrition, Ankara, Turkey.

21. Cakmak I, Kalayci M, Ekiz H, Bruan HJ, Kiline Y, et al. (1999) Zinc deficiency as a practical problem in plant and human nutrition in Turkey: A NATO-science for stability project. Field Crops Research 60(12): 175-188.
22. Iqbal TH, Lewis KO, Cooper BT (1994) Phytase activity in the human and rat small intestine. Gut 35(9): 1233-1236.

23. Mendoza C, Viteri FE, Lönnerdal B, Young KA, Raboy V, et al. (1998) Effect of genetically modified, low-phytic acid maize on absorption of iron from tortillas. Am J Clin Nutr 68(5): 1123-1127.

24. Hurrell RF, Reddy MB, Juillerat MA, Cook JD (2003) Degradation of phytic acid in cereal porridges improves iron absorption by human subjects. Am J Clin Nutr 77(5): 1213-1219.

25. Egli I, Davidsson L, Zeder C, Walczyk T, Hurrell R (2004) Dephytinization of a complementary food based on wheat and soy increases zinc, but not copper, apparent absorption in adults. J Nutr 134(5): 1077-1080.

26. Hambidge KM, Huffer JW, Raboy V, Grunwald GK, Westcott JL, et al. (2004) Zinc absorption from low-phytate hybrids of maize and their wild-type isohybrids. Am J Clin Nutr 79(6): 1053-1059.

27. Hambidge KM, Krebs KM, Westcott JL, Sian L, Miller LV, et al. (2005) Absorption of calcium from tortilla meals prepared from low-phytate maize. Am J Clin Nutr 82(1): 84-87.

28. Weaver CM, Kannan S (2002) Phytate and mineral bioavailability. In: Food Phytates. Reddy NR, Sathe SK (Eds.), CRC Press LLC, Boca Raton, Florida, USA, pp. 211-223.

29. Hussain S, Maqsood MA, Miller LV (2012) Bioavailable zinc in grains of bread wheat varierties of Pakistan. Cereal Research Communications 40(1): 62-73.

30. Gibson RS, Bailey KB, Gibbs M, Ferguson EL (2010) A review of phytate, iron, zinc, and calcium concentrations in plant-based complementary foods used in low-income countries and implications for bioavailability. Food Nutr Bull 31(2 Suppl): 134-146.

31. Hotz C, Brown KH, Rivera JA, Bhutta Z, Gibson RS, et al. (2004b) International Zinc Nutrition Consultative Group (IZiNCG) Technical Document\#1. Assessment of the risk of zinc deficiency in populations and options for its control. Food Nutr Bull 25((1 Suppl 2)): S99-203.

32. Dary O, Hurrell R (2006) Guidelines on food fortification with micronutrients. World Health Organization, Food and Agricultural Organization of the United Nations, Geneva, Switzerlans.

33. Rawat N, Neelam K, Tiwari VK, Dhaliwal HS (2013) Biofortification of cereals to overcome hidden hunger. Plant Breeding 132(5): 437-445.

34. Gomez Galera S, Rojas E, Sudhakar D, Zhu C, Pelacho AM, et al. (2010) Critical evaluation of strategies for mineral fortification of staple food crops. Transgenic Res 19(2): 165-180.

35. Diaz Gomez J, Moreno JA, Angulo E, Sandmann G, Zhu C, et al. (2017) High-carotenoid biofortified maize is an alternative to color additives in poultry feed. Anim Feed Sci Technol 231: 38-46.

36. Hirschi K (2008) Nutritional improvements in plants: time to bite on biofortified foods. Trends Plant Sci 13(9): 459-463.

37. Cakmak I (2008a) Zinc deficiency in wheat in Turkey, Chap 7, In: Micronutrient Deficiencies in Global Crop Production. Alloway BJ (Ed.), Springer, Dordrecht, Netherlands, pp. 181-200.

38. Taban S, Alpaslan M, Güneș A, Aktaș M, Erdal Ș, et al. (1997) The effect of zinc applied in different ways on yield and bioavailability of zinc in wheat plants. I National Zinc Congress, Eskișehir, Turkey, pp. 147-155.

39. Dhaliwal SS, Ram H, Shukla AK, Mavi GS (2019) Zinc biofortification of bread wheat, triticale, and durum wheat cultivars by foliar zinc fertilization. Journal of Plant Nutrition 42(8): 813-822.

40. Pavia I, Roque J, Rocha L, Ferreira H, Castro C, et al. (2019) Zinc priming and foliar application enhances photoprotection mechanisms in drought-stressed wheat plants during anthesis. Plant Physiol Biochem 140: 27-42. 
41. Liu DY, Liu YM, Zhang W, Chen XP, Zou CQ (2019) Zinc uptake, translocation, and remobilization in winter wheat as affected by soil application of Zn fertilizer. Front Plant Sci 10: 426.

42. Liu DY, Zhang W, Liu YM, Chen XP, Zou CQ (2020) Soil application of zinc fertilizer increases maize yield by enhancing the kernel number and kernel weight of inferior grains. Frontiers in plant science 11: 188.

43. Zhang L, Yan M, Li H, Ren Y, Siddique KH, et al. (2020) Effects of zinc fertilizer on maize yield and water-use efficiency under different soil water conditions. Field Crops Research 248: 107718.

44. Martínez Cuesta N, Carciochi W, Sainz Rozas H, Salvagiotti F, Colazo JC, et al. (2021) Effect of zinc application strategies on maize grain yield and zinc concentration in mollisols. Journal of Plant Nutrition 44(4): 486497.

45. Özcan H, Taban S (2012) Effect of zinc application on yield and grain zinc, phosphorus and phytic acid concentration of some rice genotypes. Journal of Soil Water 1(1): 7-14.

46. Özcan H, Taban S, Tunaboylu ÖK, Çikili Y, Taban N (2013) The effects of zinc application on the growth and zinc content of rice varieties having different kernel weights. Journal of Soil Water 2(2).

47. Özcan H, Taban S (2018) The effect of zinc application on agronomic parameters of some rice genotypes. Journal of Soil Science and Plant Nutrition 6(1): 12-18.

48. Phuphong P, Cakmak I, Yazici A, Rerkasem B, Prom u Thai C (2020) Shoot and root growth of rice seedlings as affected by soil and foliar zinc applications. Journal of Plant Nutrition 43(9): 1259-1267.

49. Girija Veni V, Datta SP, Rattan RK, Meena MC, Singh AK, et al. (2020) Effect of variability of zinc on enhancement of zinc density in basmati rice grain grown in three different soils in India. Journal of Plant Nutrition 43(5): 709-724.

50. Tang L, Hamid Y, Liu D, Shohag MJI, Zehra A, et al. (2020) Foliar application of zinc and selenium alleviates cadmium and lead toxicity of water spinach-Bioavailability/cytotoxicity study with human cell lines. Environ Int 145: 106122.

51. Gao M, Xu Y, Chang X, Dong Y, Song Z (2020) Effects of foliar application of graphene oxide on cadmium uptake by lettuce. Journal of Hazardous Materials 398: 122859.

52. Adrees M, Khan ZS, Hafeez M, Rizwan M, Hussain K, et al. (2020) Foliar exposure of zinc oxide nanoparticles improved the growth of wheat
(Triticum aestivum L.) and decreased cadmium concentration in grains under simultaneous $\mathrm{Cd}$ and water deficient stress. Ecotoxicology and Environmental Safety 208: 111627.

53. Rafie MR, Khoshgoftarmanesh AH, Shariatmadari H, Darabi A, Dalir $\mathrm{N}$ (2017) Influence of foliar-applied zinc in the form of mineral and complexed with amino acids on yield and nutritional quality of onion under field conditions. Scientia Horticulturae 216: 160-168.

54. Tabesh M, Kiani S, Khoshgoftarmanesh AH (2020) The effectiveness of seed priming and foliar application of zinc-amino acid chelates in comparison with zinc sulfate on yield and grain nutritional quality of common bean. Journal of Plant Nutrition 43(14): 2106-2116.

55. Yilmaz A, Ekiz H, Torun B, Gultekin I, Karanlik S, et al. (1997) Effect of different zinc application methods on grain yield and zinc concentration in wheat cultivars grown on zinc-deficient calcareous soils. J Plant Nutr 20(4-5): 461-471.

56. Rosado JL, Hambidge KM, Miller LV, Garcia OP, Westcott J, et al. (2009) The quantity of zinc absorbed from wheat in adult women is enhanced by biofortification. J Nutr 139(10): 1920-1925.

57. Özcan H (2004) The effect of zinc application on yield and grain zinc, phosphorus and phytic acid concentration of some rice genotypes. Ankara University, Graduate School of Natural and Applied Sciences, Department of Soil Science and Plant Nutrition, Ankara, Turkey, p. 116.

58. Cakmak I (2008b) Enrichment of cereal grains with zinc: agronomic or genetic biofortification? Plant and Soil 302: 1-17.

59. Moran K (2004) Micronutrient product types and their development. Proceedings No. 545, International Fertiliser Society, York, UK, pp. 1-24.

60. Mortvedt JJ, Gilkes RJ (1993) Zinc fertilisers. Chap 3, In: Zinc in Soils and Plants, Robson AD (Ed.), Kluwer Academic Publishers, Dordrecht, Netherlands, pp. 33-44.

61. Ghasemi S, Khoshgoftarmanesh AH, Afyuni M, Hadadzadeh H (2013) The effectiveness of foliar applications of synthesized zinc-amino acid chelates incomparison with zinc sulfate to increase yield and grain nutritional quality of wheat. Eur J Agric 45: 68-74.

62. Ortiz Lopez A, Chang HC, Bush DR (2000) Amino acid transporters in plants. Biochim Biophys Acta 1465(1-2): 275-280.

63. Kutman UB, Ylldız B, Cakmak I (2011) Effect of nitrogen on uptake, remobilization and partitioning of zinc and iron throughout the development of durum wheat. Plant and Soil 342: 149-164. 